\title{
A Fluorescent-Labeled Microcystin-LR Terbium Cryptate
}

\author{
Eduardo J. A. Oliveira, ${ }^{*, a, b}$ Suzana P. Vila Nova, ${ }^{c}$ Severino Alves-Jr, ${ }^{c}$ Petrus Santa-Cruz, ${ }^{c}$ \\ Renato J. R. Molica, ${ }^{d}$ Antonio Teixeira, ${ }^{e}$ Elizabete Malageño ${ }^{a}$ and José L. Lima Filho ${ }^{a}$ \\ ${ }^{a}$ Laboratório de Imunopatologia Keizo Asami, Universidade Federal de Pernambuco, 50670-901 Recife-PE, Brazil \\ ${ }^{b}$ Centro Federal de Educação Tecnológica de Pernambuco, 50740-540 Recife-PE, Brazil \\ ${ }^{c}$ Departamento de Química Fundamental, Universidade Federal de Pernambuco, 50740-540 Recife-PE, Brazil \\ ${ }^{d}$ Associação Instituto de Tecnologia de Pernambuco, 50740-540 Recife-PE, Brazil \\ ${ }^{e}$ Faculdade de Medicina, Universidade de Brasília 70910-700 Brasília-DF, Brazil
}

\begin{abstract}
Um novo composto fluorescente de microcistina-LR marcado com criptato de térbio foi obtido pela conjugação inicial da microcistina-LR com aminoetanotiol, seguido pela reação com o grupo éster do criptato de térbio. A formação do produto foi acompanhada por cromatografia líquida de alta eficiência (CLAE) em $238 \mathrm{~nm}$ e $310 \mathrm{~nm}$. A presença de microcistinaLR na molécula marcada foi confirmada através de ensaio com enzima ligada a imunoabsorvente (ELISA) e por reação protéica com ácido bicincônico. O espectro de luminescência do criptato e da molécula conjugada também foram confirmados.
\end{abstract}

\begin{abstract}
A new fluorescent labeled compound of microcystin-LR with terbium cryptate was obtained by initial conjugation of microcystins-LR with aminoethanethiol followed by the reaction with the ester group of terbium cryptate. The product formation was followed by high performance liquid chromatography (HPLC) at $238 \mathrm{~nm}$ and $310 \mathrm{~nm}$. The presence of microcystin-LR in the labeled molecule was confirmed by enzyme linked immunosorbent assay ELISA and by protein reaction with bicinhonic acid. Luminescence spectra of cryptate and the conjugated molecule were carried through as well.
\end{abstract}

Keywords: terbium cryptate, microcystin-LR, cyanobacteria

\section{Introduction}

Microcystins are a group of stable heptapeptide hepatotoxins produced by freshwater cyanobacteria genera that lower the water quality leading to an increase in the risk of intoxication for animals and humans. Species of genera Microcystis, Anabaena, Aphanizomenon, Planktothrix (Oscillatoria), and Nostoc are frequently described as producers of microcystins. ${ }^{1}$ The eutrophication of ponds, rivers and other freshwater ecosystems allows cyanobacteria to flourish, leading to contamination of the water. ${ }^{2}$

Microcystins are potent inhibitors of protein phosphatases $1\left(\mathrm{PP}_{1}\right)$ and $2 \mathrm{~A}\left(\mathrm{PP}_{2 \mathrm{~A}}\right)$, which are regulatory enzymes present in the cytosol of mammalian cells. ${ }^{3}$ The general structure of microcystins is composed of cyclo-(D-Ala-X-D-MeAsp-ZAdda-D-Glu-Mdha), where $\mathrm{X}$ and $\mathrm{Z}$ could be various kinds

* e-mail: edualec@oi.com.br of L-amino acids; D-MeAsp is D-erythro- $\beta$-methylaspartic acid; Mdha is N-methyldehydroalanine; and Adda is the unusual amino acid 2S,3S,8S,9S-3-amino-9-methoxy-2,6,8trimethyl-10-phenyldeca-4E,6E-dienoic acid. ${ }^{4}$ The most extensively studied form is microcystin-LR that contains L-leucine and L-arginine in the two main variant positions. ${ }^{3}$ More than 60 different analogues of microcystins have been described and their acute mouse i.p. toxicity $\left(\mathrm{DL}_{50}\right)$ varies between $50-600 \mu \mathrm{g} \mathrm{kg}^{-1}$.

Contamination of surface drinking water by microcystin-producing cyanobacteria is a probable cause of primary liver cancer. ${ }^{5}$ Chronic oral ingestion of a crude extract of Microcystis suggests that microcystins can cause tumors after long-term exposure. ${ }^{6}$ Human mortalities resulting from oral consumption of cyanotoxins have been suspected but not confirmed, due the difficulty of obtaining reliable data regarding vectors and the circumstances that would confirm the presence of cyanotoxins in human food 
or water supplies. ${ }^{7}$ Increasing care is being taken in the consumption of products contaminated with cyanobacteria toxins, because of the risks involved in consuming food that contains blue-green algae or water contaminated by their toxins. ${ }^{8}$ Recently, an acute case of poisoning of humans undergoing haemodialysis with water contaminated with microcystin killed 76 of a total of 131 patients in the city of Caruaru in Northeast Brazil. ${ }^{7,9,10}$ As a consequence, a microcystin limit of $1 \mu \mathrm{g} \mathrm{L}^{-1}$ was established for drinking water in Brazil. ${ }^{11}$

Currently, the aim is to develop a fast, inexpensive and convenient analytical method for detecting microcystins. Immunological fluorescent methods using antigen, monoclonal or polyclonal antibody have become a wellknown protocol. ${ }^{12-16}$ Fluorescent-labeled reagents have been developed for biological applications. Kim et. al. ${ }^{17}$ employed a one-step fluorescence immunochromatographic assay to quantify microcystins using Alexa Fluor 647. A fluorescent phosphatases enzyme inhibition assay for microcystin-LR was developed by Fontal et $a .^{3}$

Complexes with a lanthanide ion, when excited by ultraviolet (UV) radiation, show long-lasting luminescence and are excellent light conversion molecular devices, LCMD's ${ }^{18}$ applied in time-resolved microscopy, ${ }^{19}$ fluorescent lighting, ${ }^{20} \mathrm{UV}$ dosimeters, ${ }^{21}$ antirefelection coatings for solar cells, ${ }^{22}$ and the labeling of biological assays. ${ }^{23,24}$

In the search for more sensitive markers, some chelates of lanthanides had already been obtained and tested in various biological assay models. ${ }^{25-27}$ Time-resolved fluoroimmunometric assay (TR-FIA) is a method based on the luminescence emission that is measured after a delay has elapsed from a pulsed excitation, enabling the short-lived background fluorescence to be excluded. ${ }^{28}$ Soini et. al. ${ }^{29}$ labeled anti-rabbit IgG with europium chelate as a model to detect rabbit $\mathrm{IgG}$ for human smooth muscle myosin in a histological section; Bonin et al..$^{30}$ used a complex of europium and samarium for the detection of diphteria antitoxins in serum using the ELISA method and $\mathrm{Xu}$ et al. $^{31}$ labeled anti- $\beta$-LH and monoclonal anti- $\beta$ FSH antibodies with europium and samarium, respectively. The use of luminescent lanthanide as a substitute for labeled enzyme (e.g. horseradish peroxidase - HRP) in the ELISA method for microcystin detection has been described by Mehto et al. ${ }^{28}$ This system uses microcystinLR labeled with a europium chelate.

One of the classes of lanthanide complexes that is increasingly being used in immunological assays is the cryptates. These compounds are highly stable when dissolved in water, and have a high coefficient of molar absorption, a high quantum yield in water solution and kinetic and thermodynamic stability. ${ }^{32}$ Europium cryptate also has been used for labeling $\mathrm{DNA}^{33}$ and antibodies, ${ }^{34}$ and the Cis-Bio-Schering Company (France) has now put on the market a kit with trisbipyridine europium cryptate for labeling biomolecules. Terbium complex has been used in thin films as very efficient light converters under UV excitation, where the ligands act as antennas, absorbing UV radiation and efficiently transferring energy to $\mathrm{Tb}^{3+}$ emitters. The green emission, ${ }^{5} \mathrm{D}_{4}$ à ${ }^{7} \mathrm{~F}_{5}$, transition is monitored as function of UV excitation. ${ }^{18}$ The use of a terbium cryptate for labeling cyanotoxins, however, has not been investigated yet.

There is obviously a need to monitor cyanotoxins in water samples and products that may have previously been in contact with cyanobacteria.

This paper describes how a new luminescent terbium cryptate conjugate with microcystin-LR was synthesized and characterized.

\section{Experimental}

\section{Materials and methods}

The water used was purified by distillation or deionization followed by purification via Milli-Q water system (Millipore), producing water with $18.2 \mathrm{M} \Omega \mathrm{cm}$ resistivity. All other reagents, where not specified, were of analytical or liquid chromatographic grade.

\section{Terbium cryptate synthesis}

The labels (a), (b) and (c) refer to the intermediate compounds shown in Figure 1. The synthesis of the cryptates was achieved by bromination of diethyl 2,6-dimethyl-3,5pyridinedicarboxilate (99\% Aldrich), via the initiator 1,1'-Azo (cyclohexanecarbonitrile) (98\% Aldrich) and N-bromosuccinimide (NBS, 99\% Aldrich) under reflux and irradiation by a $100 \mathrm{~W}$ incandescent lamp to give 2,6-dibromomethyl-3,5-diethyl-dicarboxilate (a). The bromination of 6,6'-dimethyl-2,2'-bipyridine used benzoyl peroxide associated with NBS. ${ }^{35,36}$ In this procedure the product 6,6'-Bis (bromomethyl)-2,2'-bipyridine (b) is obtained in the pure state after re-crystallization. The ring (c) was synthesized following the procedure described in the literature. ${ }^{35,37}$ The subsequent step was the formation of the cryptate $\left[\mathrm{Li} \subset\right.$ bpy.bpy.py $\left.\left(\mathrm{CO}_{2} \mathrm{Et}\right)_{2}\right] \mathrm{CO}_{3}^{-}$. The product (c) was added to $\mathrm{CH}_{3} \mathrm{CN}_{(\text {aq) }}$ in an atmosphere of $\mathrm{N}_{2(\mathrm{~g})}$. The product (a) was dissolved in an aqueous solution of $\mathrm{Li}_{2} \mathrm{CO}_{3}$ under reflux. The cryptate thus formed (d), was purified using HPLC. The inclusion of the terbium ion in the cryptate was achieved by single ionic change with $\mathrm{Li}^{+}$cation and the lanthanide (e). ${ }^{38,39}$ 
The lanthanide cryptate was purified by HPLC and characterized by UV-VIS and IR spectroscopies and mass spectrometry. The UV-VIS absorption spectrum for an ethanolic solution of terbium cryptate $\left(10^{-5} \mathrm{~mol} \mathrm{~L}^{-1}\right)$ presented maximum intensities at $208 \mathrm{~nm}, 243 \mathrm{~nm}$ and $291 \mathrm{~nm}$. The product analised by IR with $\mathrm{KBr}$ disk for transmission analysis showed the main bands at $3138.2 \mathrm{~cm}^{-1}, 2938.3$ $\mathrm{cm}^{-1}, 1685.0 \mathrm{~cm}^{-1}, 1436.1 \mathrm{~cm}^{-1}, 1206.3 \mathrm{~cm}^{-1}$ and 1130.8 $\mathrm{cm}^{-1}{ }^{38,39}$ The proposed formulae of the cryptates synthesized are also consistent with the mass spectrometry results:

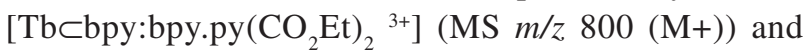
[Licbpy:bpy:py $\left.\left(\mathrm{CO}_{2} \mathrm{Et}\right)_{2}\right] \mathrm{Br}$ (MS m/z, $\left.728(\mathrm{M}+)\right)^{38,39}$

\section{Microcystin-LR-terbium cryptate conjugation}

First stage: conjugation of microcystin-LR to aminoethanethiol. Microcystin-LR (Sigma) was dissolved in a mixture of 20 percent methanol and 80 percent $100 \mathrm{mmol}$ $\mathrm{L}^{-1}$ phosphate buffer ( $\mathrm{pH}$ 7.0) to a final concentration of 5.0 $\mathrm{mg} \mathrm{mL} \mathrm{L}^{-1}$ and it was maintained at $-20^{\circ} \mathrm{C}$. In the first stage of conjugation, $13.9 \mathrm{mg}$ of 2-aminoethanethiol hydrochloride (Sigma) was added to $60 \mu \mathrm{g}$ of microcystin-LR in a molar excess of 3,000-fold. The reaction was carried out in a solution of $24 \mu \mathrm{L}$ of dimethyl sulfoxide (Merck), $18 \mu \mathrm{L}$ of purified water and $8 \mu \mathrm{L}$ of $5.0 \mathrm{~mol} \mathrm{~L}^{-1} \mathrm{NaOH}$. The mixture was incubated for one hour at $50^{\circ} \mathrm{C}$ under nitrogen, followed by the addition of $62 \mu \mathrm{L}$ of concentrated acetic acid and $496 \mu \mathrm{L}$ of Trifluoracetic acid $0.1 \%(\mathrm{pH} 1.5)$ as suggested by Moorhead et al..$^{40}$ Before the purification of conjugated microcystin-LR-aminoethanethiol, a mixture of equal parts of the reaction and microcystin-LR solution of the same concentration was injected to verify the retention times. The conjugate was purified by HPLC, frozen-dried (ModulyoD, ThermoSavant) and suspended in $200 \mu \mathrm{L}$ of $50 \mathrm{mmol} \mathrm{L}^{-1} \mathrm{NaHCO}_{3}, 0.15 \mathrm{~mol} \mathrm{~L}^{-1} \mathrm{NaCl}$ buffer (pH 8.5).

Second stage: conjugation of microcystin-LR- aminoethanethiol to terbium cryptate. The reaction was carried out in molar excess of 25:1 cryptate: microcystin-LRaminoethanethiol for a 24-hour period $\left(\mathrm{t}_{\mathrm{oh}}-\mathrm{t}_{24 \mathrm{~h}}\right)$. Purified terbium cryptate $(1.7 \mathrm{mg})$ was dissolved in $200 \mu \mathrm{L}$ of 50 mmol L ${ }^{-1} \mathrm{NaHCO}_{3}, 0.15 \mathrm{~mol} \mathrm{~L}^{-1} \mathrm{NaCl}$ buffer ( $\mathrm{pH} 8.5$ ) and mixed with $200 \mu \mathrm{L}$ of the microcystin-LRaminoethanethiol solution and incubated at ambient temperature for 24 hours.

\section{High-Performance Liquid Chromatography (HPLC)}

Microcystin-LR, microcystin-LR-aminoethanethiol, terbium cryptate and all reactions were analyzed using HPLC. The system consisted of a Shimadzu (Kyoto, Japan) LC-10ATvp pump and a column $\mathrm{C}_{18}$ LichroCart with $5 \mu \mathrm{m}$

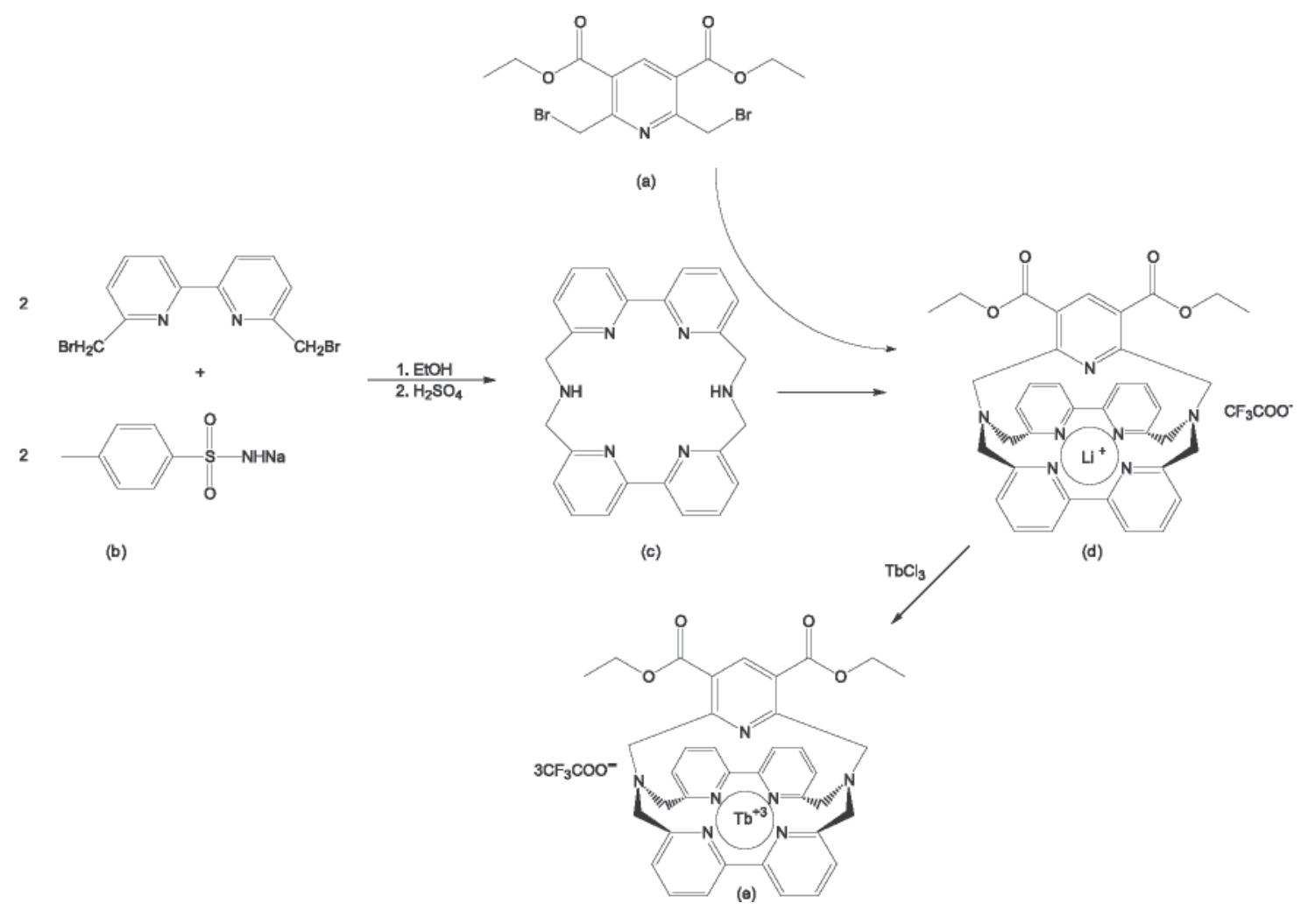

Figure 1. Schematic synthesis of terbium cryptate. 
particle size, 250x4 mm (Merck) attached to a UV detector (SPDM-10Avp). Samples of $50 \mu \mathrm{L}$ were injected and separation was accomplished using a reverse phase gradient and a mobile phase of acetonitrile: $1.0 \%(\mathrm{v} / \mathrm{v})$ TFA at rate of flow of $1.0 \mathrm{~mL} \mathrm{~min}^{-1}$ at $40^{\circ} \mathrm{C}$. The linear gradient starting at $15 \%(\mathrm{v} / \mathrm{v})$ acetonitrile and increasing to $100 \%$ over 35 min and maintained for $40 \mathrm{~min}$. The acetonitrile was then reduced by $15 \%$ for $45 \mathrm{~min}$ and kept at this ratio until 55 min had elapsed and afterwards, a new injection was administered. Detector resolution was set at $1.0 \mathrm{~nm}$ and the reaction monitored at $238 \mathrm{~nm}$ and $310 \mathrm{~nm}$. The fractions of terbium-microcystins-LR conjugation were collected, pooled, frozen-dried and suspended in $500 \mu \mathrm{L}$ of purified water so as it could be used in the fluorescence assays (luminescence), ELISA and protein reaction.

\section{Luminescence spectroscopy}

The fraction corresponding to the terbium cryptate and the terbium-microcystin-LR conjugated, obtained at the end of the HPLC purification, were analyzed by emission spectroscopy. The luminescence spectra were measured at $300 \mathrm{~K}$ using a Jobin Yvon double monochromator model U-1000 Ramanor attached to a water-cooled RCA C310340-02 photomultiplier. In this case, a 450 UV Xe lamp was used as the source of excitation. The registering and processing of the signal were carried out using a Spectralink interface to an IBM microcomputer.

\section{Purification of anti-microcystin-LR-KLH antibodies}

The affinity column of protein $\mathrm{G}$ (HiTrap, Amersham, London, UK) was stabilized with $5 \mathrm{~mL}$ of $20 \mathrm{mmol} \mathrm{L}^{-1}$ phosphate buffer ( $\mathrm{pH}$ 7.0). Nine milliliters of the rabbit serum anti-microcystin-LR-KLH were applied in portions of $0.5 \mathrm{~mL}$ and the column washed with $5.0 \mathrm{~mL}$ of the same buffer. The fraction of interest was extracted with $3.0 \mathrm{~mL}$ of $0.1 \mathrm{~mol} \mathrm{~L}^{-1}$ glicina- $\mathrm{HCl}$ buffer $(\mathrm{pH} 2.7)$ directly into a tube that contained $0.3 \mathrm{~mL}$ of $0.1 \mathrm{~mol}$ $\mathrm{L}^{-1}$ tris- $\mathrm{HCl}$ buffer ( $\mathrm{pH} 9.0$ ). The solution of $\mathrm{IgG}$ was reduced to a volume of approximately $200 \mu \mathrm{L}$ using a Centricon tube of $30 \mathrm{KD}$. The final concentration of antibodies was determined by the total protein analysis. ${ }^{41}$

\section{Competitive indirect ELISA}

The assay used was developed by Karnikowski for analysis of microcystins. ${ }^{42}$ The aqueous fraction of terbiummicrocystins-LR conjugation and the fraction corresponding to the terbium cryptate obtained at the end of the HPLC purification were diluted in $1 / 10$ in the same buffer used for microcystin-LR standards. A blank of water and buffer was utilized. All samples and standards were analysed three times. This assay is an indirect competitive enzyme immunoassay on a 96-well microtiter plate (Maxisorp, Nunc, Roskilde, Denmark) coated with microcystin-LRovoalbumin. The standard curve was achieved with microcystin-LR solutions of $0.16,1.6,5.0$ and $10.0 \mu \mathrm{g} \mathrm{L}^{-1}$. In summary, $50 \mu \mathrm{L}$ of a solution of the equal parts of sample or microcystin-LR standard with the antibody were incubated for $90 \mathrm{~min}$ at $37^{\circ} \mathrm{C}$ and pipetted into the well and incubated for 2 hours at ambient temperature. The wells were emptied and washed three times with $200 \mu \mathrm{L}$ of 15 mmol L-1 phosphate buffer $-0.05 \%$ Tween ( $\mathrm{pH}$ 7.2). A 50 $\mu \mathrm{L}$ aliquot of polyclonal anti-rabbit IgG (whole molecule)Peroxidase from goat (Sigma-Aldrich Co.) diluted $1: 2,000$ was added and incubated for another $90 \mathrm{~min}$ at $37^{\circ} \mathrm{C}$. The wells were washed again. An aliquot of $50 \mu \mathrm{L}$ of substrate o-phenilenediamine (OPD, Sigma ) was added to each well and incubated for $10 \mathrm{~min}$ at ambient temperature and protected from light. Finally, $50 \mu \mathrm{L}$ of a $3.0 \mathrm{~mol} \mathrm{~L}^{-1}$ hydrochloric solution was added to stop the reaction and the absorbance immediately recorded at $492 \mathrm{~nm}$ using a microplate reader ( EIA/ELISA reader mod. 2550, Biolab).

\section{Protein analysis}

The aqueous fraction of terbium-microcystin-LR conjugation and terbium cryptate obtained at the end of HPLC purification were tested for the protein reaction utilizing a bicinchonic acid protein assay kit (Pierce art. 23255).

\section{Results and Discussion}

\section{Microcystin-LR-terbium cryptate conjugation}

No peak was detected in the HPLC analysis at the wavelengths of $238 \mathrm{~nm}$ and $310 \mathrm{~nm}$ after injection of 50 $\mu \mathrm{L}$ of bicarbonate buffer and aminoethanethiol used for the conjugation of microcistin-LR to terbium cryptate. The microcystin-LR standard, when injected separately, showed a peak at $238 \mathrm{~nm}$ after $22.6 \mathrm{~min}$ and no peak at $310 \mathrm{~nm}$. The chromatogram of a mixture of equal parts of microcystin-LR and microcystin-LR-aminoethanethiol after reaction $\left(1\right.$ hour, $\left.50{ }^{\circ} \mathrm{C}\right)$ showed two peaks at 238 $\mathrm{nm}$, one within $22.6 \mathrm{~min}$ and another after $21.5 \mathrm{~min}$ respectively, showing good separation under analytical test conditions (Figure 2). The injection of the reactional mixture microcystin-LR-aminoethanethiol $\left(\mathrm{t}_{24 \mathrm{~h}}\right)$ alone confirmed the appearance of only one peak after $21.5 \mathrm{~min}$ (data not shown). 


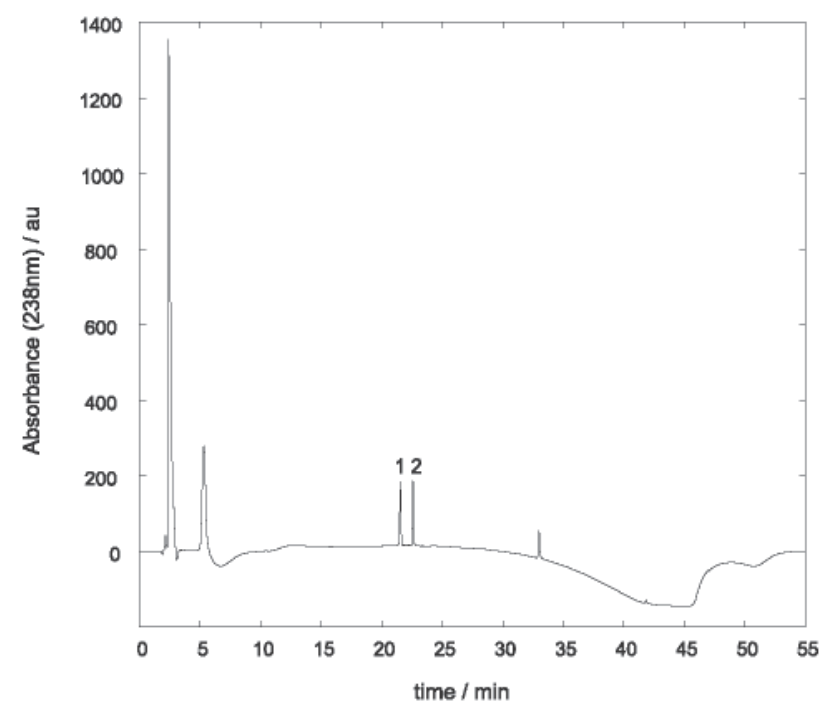

Figure 2. Chromatogram in gradient reversed-phase HPLC of mixture of reaction product: (1) microcystin-LR-aminoethanethiol and (2) microcystin-LR standard.
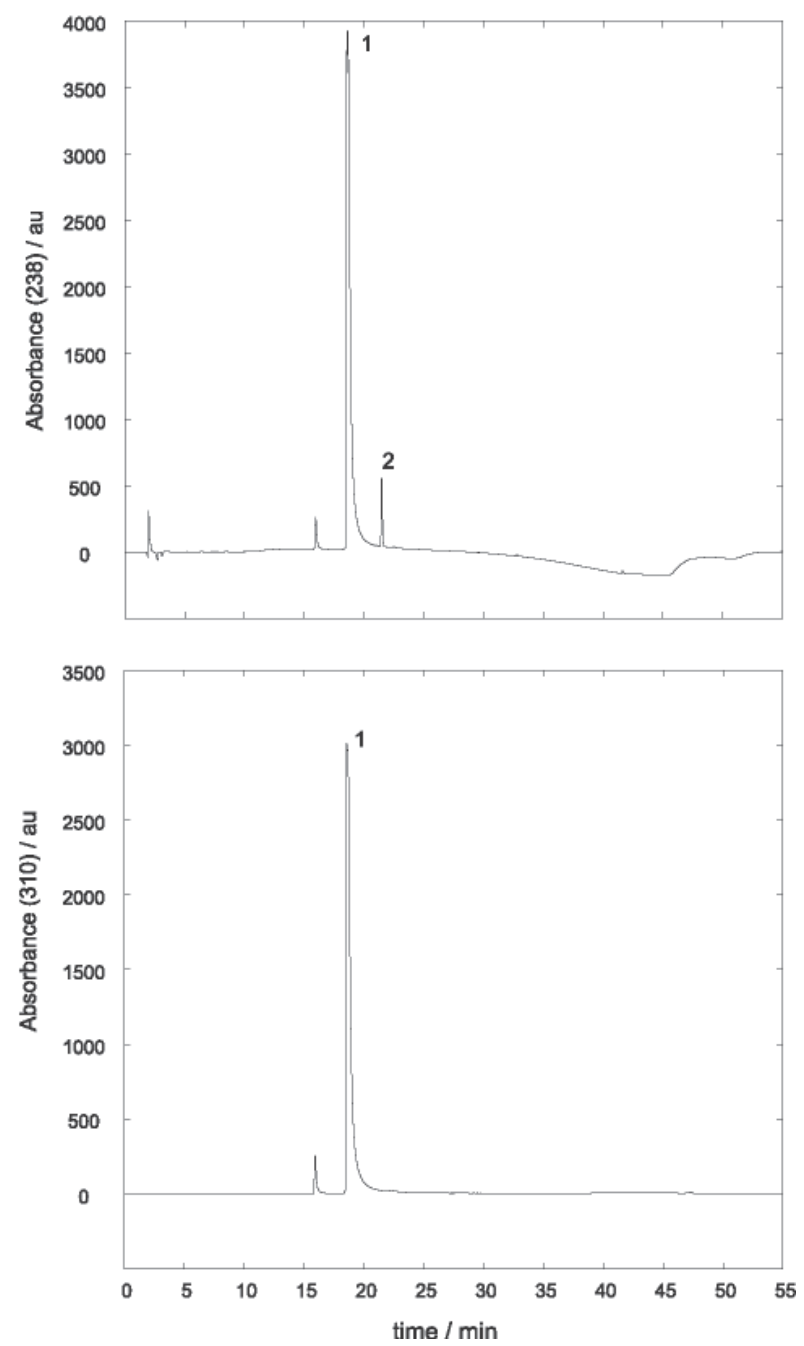

Figure 3. Chromatogram in gradient reversed-phase HPLC at the beginning of conjugation time $\left(\mathrm{t}_{\mathrm{oh}}\right)$ of microcystin-LR-aminoethanethiol and terbium cryptate at $238 \mathrm{~nm}$ and $310 \mathrm{~nm}$ : (1) Terbium cryptate and (2) Microcystin-LR-aminoethanethiol.
Purified terbium cryptate dissolved in a $\mathrm{NaHCO}_{3}$ buffer showed a main peak after $18.6 \mathrm{~min}$ at $238 \mathrm{~nm}$ and $310 \mathrm{~nm}$ (data not shown). The same retention times of the isolated products, terbium cryptate and microcystin-LRaminoethanethiol, were observed at the beginning of the conjugation, $\mathrm{t}_{\mathrm{oh}}$ (Figure 3). A small peak after $15.9 \mathrm{~min}$ was also observed at the beginning of the conjugation at $238 \mathrm{~nm}$ and also at $310 \mathrm{~nm}$.

After $24 \mathrm{~h}$ of reaction $\left(\mathrm{t}_{24 \mathrm{~h}}\right)$ a sharp peak was observed within $15.9 \mathrm{~min}$ and an slightly less intense peak after 18.6 min (Figure 4).

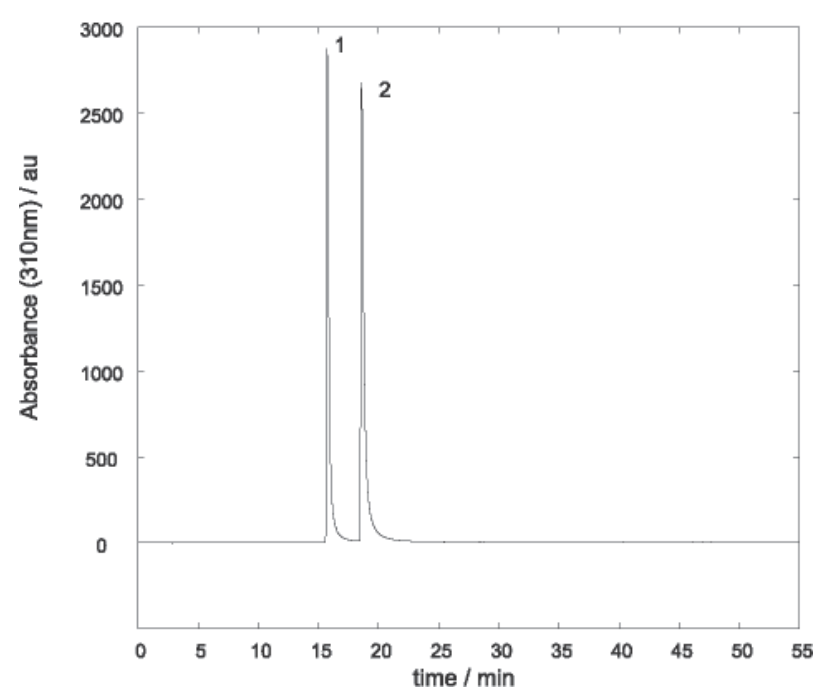

Figure 4. Chromatogram in gradient reversed-phase HPLC at the final conjugation time $\left(\mathrm{t}_{24 \mathrm{~h}}\right)$ of microcystin-LR-aminoethanethiol and terbium cryptate at $310 \mathrm{~nm}$ : (1) Microcystin-LR-Terbium cryptate and (2) Terbium cryptate.

The luminescence spectra of the isolated fractions of terbium-microcystin-LR and terbium cryptate proved to be characteristic of metallic ion as represented in the Figure 5.

The standard ELISA curve used as standard showed a good correlation coefficient $(r=0.9346 ; \mathrm{t}=8.3 ; \mathrm{p}<0.01)$

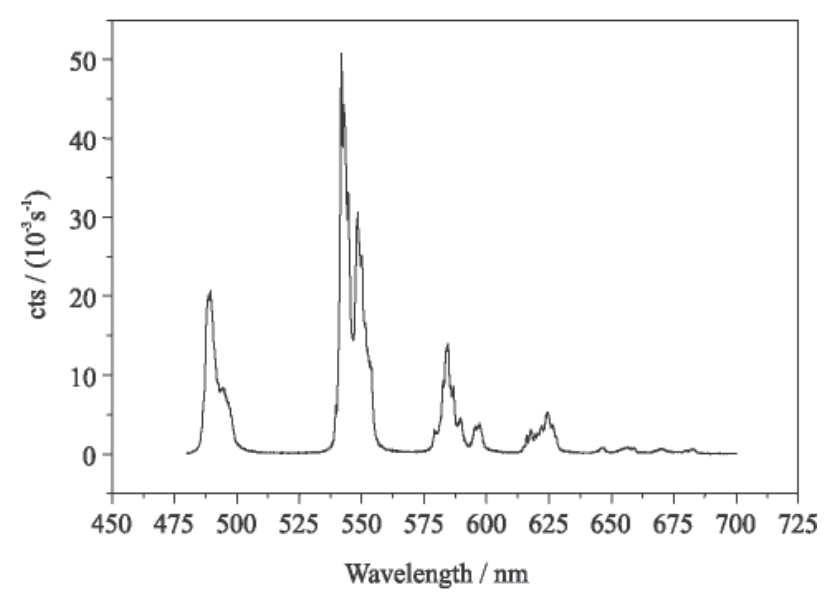

Figure 5. Emission spectra of microcystin-LR-terbium cryptate fraction obtained in gradient reversed-phase HPLC. Excitation wavelength: $310 \mathrm{~nm}$. 
during the interval from $0.16 \mu \mathrm{g} \mathrm{L}^{-1}$ to $10.0 \mu \mathrm{g} \mathrm{L}^{-1}$ (Figure $6)$. The fraction of microcystin-LR-terbium cryptate conjugation diluted $1 / 10$, showed a $43.3 \%$ inhibition of antibody response while that corresponding to the terbium cryptate and the blank did not show inhibition.

The aqueous fraction of terbium-microcystin-LR conjugation was tested positive for protein using bicinchonic acid reaction, while the fraction of terbium cryptate did not.

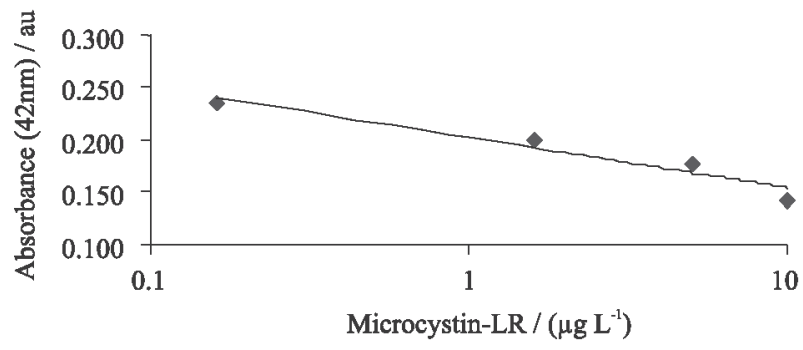

Figure 6. Semi-log graphic of competitive indirect ELISA of standard microcystin-LR using anti-microcystin-LR-KHL IgG on a microplate coated with microcystin-LR- chiken ovoalbumin $(n=3)$.

There is an increasing demand for more sensitive and inexpensive analytical methods to deal with lower detection limits and this has given rise to a need for more sensitive labeling.

A luminescent complex of microcystin-LR-terbium cryptate was developed for microcystin analysis.

The microcystin-LR was used because it is one of the most common microcystins ${ }^{28}$ and is the most hepatotoxic among microcystins. ${ }^{1}$ Moreover, it is recommended to evaluate its concetration in water in various countries, including Brazil, ${ }^{11}$ Great Britain and other European countries $^{43}$ and the World Health Organization - WHO also recommended a provisional standard level of $1.0 \mu \mathrm{g}$ $\mathrm{L}^{-1}$ for drinking water. ${ }^{44}$

The cryptate of terbium is very advantageous because terbium is not so sensitive to aqueous quenching and the efficient energy transference from ligand triplet state to the excited metallic state overcomes the difficulty of the use of terbium chelates in bioanalytical applications. ${ }^{24}$ Terbium cryptate molecule is also of small dimension when compared with chicken egg albumin (44,000 Da), horseradish peroxidase $(44,000 \mathrm{Da})$ or IgG antibodies (150,000 Da) - molecules normally used in immunoassays - thereby minimizing the possibility of steric hindrance. The cryptate as biomolecule labeling groups, in contrast of chelates, has the advantage of being directly conjugated without a displacement step. ${ }^{33}$

The microcystin-LR conjugation with aminoethanethiol was chosen because it is known that the reaction occurs with the amino acid methyldehydroalanine (Mdha) of the toxin ${ }^{40,45}$ in a position that does not interfere with the main antigenic region of the molecule, the Adda amino acid.

The following reaction is proposed for the conjugation of toxin with terbium cryptate. It is based on the reaction presented by Metho et $a l .{ }^{28}$ for linking microcystin-LR with europium chelate (Figure 7).

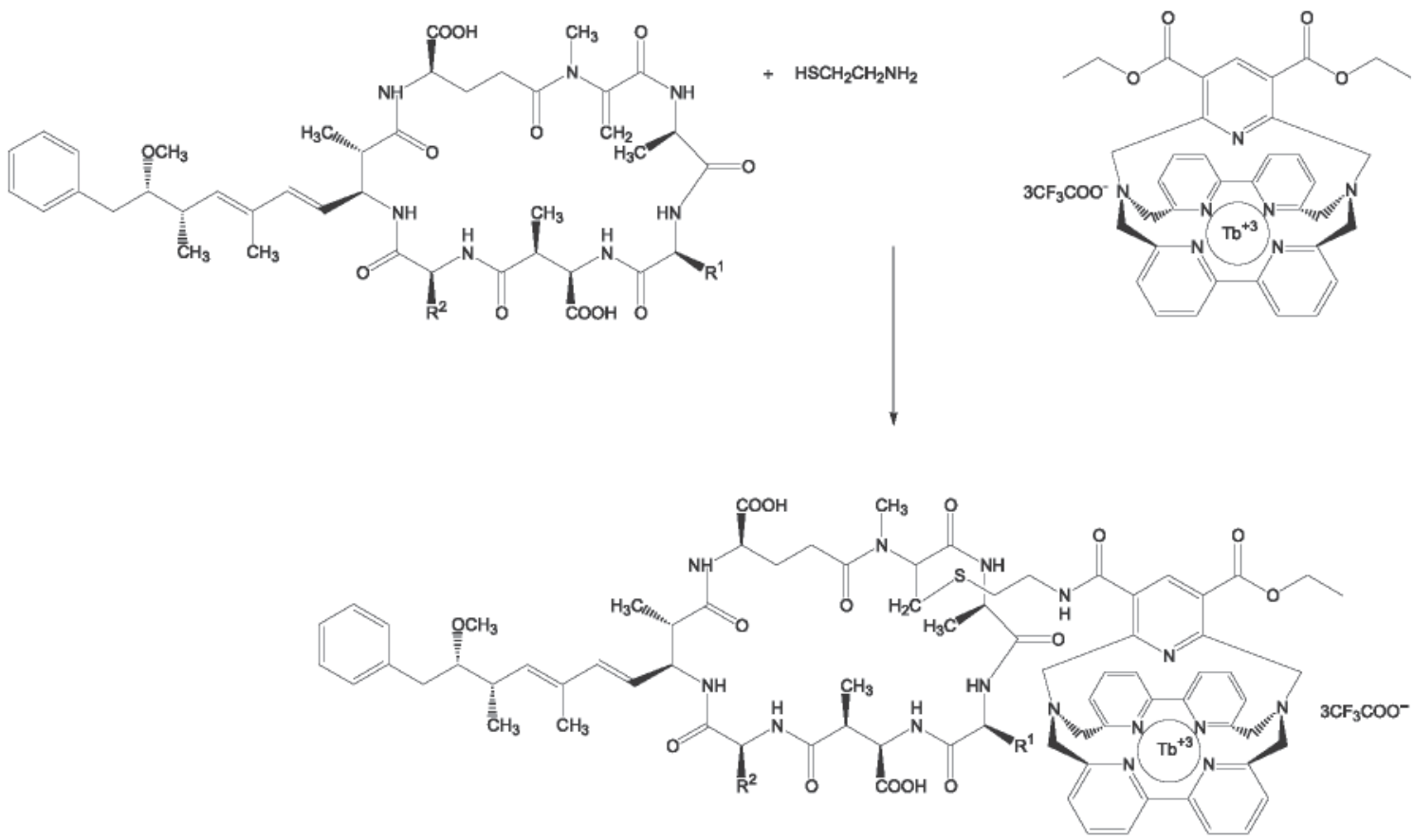

Figure 7. Microcystin-LR terbium cryptate conjugation reactions. 
Microcystin-LR reacted, in its entirety, with the low molecular weight aminoethanethiol, as confirmed by HPLC: a single peak after $21.5 \mathrm{~min}$ (chromatogram not shown) was detected. Therefore, it could be successfully resolved from microcystin-LR standard (Figure 2) allowing it to be recovered for the subsequent reaction. According to Moorhead et al. ${ }^{40}$ the reaction of aminoethanethiol with the carbonyl group of the Mdha residue is stronger at a high $\mathrm{pH}$ value, producing more than $95 \%$ of intermediate product.

The link inhibition of antibody with microcystin-LRchicken ovoalbumin, in the ELISA plate, by the conjugate (peak 1, Figure 4) demonstrates the immunoreagent capacity and confirms the microcystin presence in the structure. In accordance with Lopez et al. ${ }^{34}$ trisbipyridine diamine europium cryptate was conjugated to antibody by the method utilized here without any loss of immunoreactivity. The structure of the hydrophobic amino acid Adda, which has the (E) form at the C-6 double bond is essential for determining antibody specificity ${ }^{13}$ and was preserved because the reaction occurred selectively in the amino acid methyldehydroalanine. ${ }^{40,45}$

The presence of the toxin in this molecule is strengthened by a positive protein reaction in this fraction when using the bicinchonic acid method, whose sensitivity is for structures with up to four amino acids. The conjugation of the microcystin-LR is also confirmed by the luminescence spectra of isolated cryptate and the microcystin-LR-terbium cryptate fraction.

The terbium criptate used in microcystin-LR conjugation has a high emission quantum yield in aqueous solution $\left(\mathrm{q}_{298 \mathrm{~K}}=25 \%\right.$ at $\left.\lambda_{\text {exc }}=320 \mathrm{~nm}\right),{ }^{38}$ which makes its use as, e.g, antigen in a ELISA competitive assay through TR-FIA method, that presents some advantages such as sensitivity, safety, convenience and ease for automation. ${ }^{46}$

\section{Acknowledgments}

The authors acknowledge to the CNPq, FACEPE (Brazilian agencies) for financial support and Parente, Bruno by graphical elaboration.

\section{References}

1. Chorus, I.; Bartram, J.; Toxic Cyanobacteria in Water: A Guide to their Public Health Consequences, Monitoring and Management, E \& FN Spon: London, 1999, p.416.

2. Smith, S.H. In Successes Limitations, and Frontiers in Ecosystems Science; Pace, M.L.; Groffman, P.M., eds.; Springer: New York 1998, p. 7-49.

3. Fontal, O.I.; Vieytes, M.R.; Baptista de Souza, J.M.V.; Louzao, M.C.; Botana, L.M.; Anal. Biochem. 1999, 269, 289.
4. Carmichael, W.W.; Beasley, V.R.; Bunner, D.L.; Eloff, J.E.; Falconer, L.; Gorham, P.; Harada, K.L.; Krishnamurthy, T.; MinJuan, Y.; Moore, R.E.; Rinehardt, K.; Runnegar, M.; Skulberg, O.M.; Watanabe, M.; Toxicon 1988, 26, 971.

5. Ueno, Y.; Nagata, S.; Tsutsumi, T.; Hasegawa, A.; Watanabe, M.F.; Park, H.; Chen, G.; Chen, G.; Yu, S.; Carcinogenesis 1996, 17, 1317.

6. Falconer, I.R. In Toxic Cyanobateria in Water - A Guide to Their Public Health Consequences, Monitoring and Management; Chorus, I.; Bartram, J., ed.; E \& FN Spon: London, 1999.

7. Azevedo, S.M.F.O.; Carmichael, W. W.; Jochimsen, E.M.; Rinehart, K.L.; Lau, S.; Shaw, G.R.; Eaglesham, G.K.; Toxicology 2002, 181-182, 441.

8. Gilroy, D.J.; Kauffman, K.W.; Hall, R.A.; Huang, X.; Chu, F.S.; Environ. Health Persp. 2000, 5, 435.

9. Jochimsen, E.M.; Charmichael, W.W.; AN, J.; Cardo, D.M.; Cookson, S.T.; Holmes, C.E.M.; Antunes, M.B.; Filho, D.A.D.; Lyra, T.M.; Barreto, V.S.; Azevedo, S.M.F.O.; Jarvis, W.R.; New Engl. J. Med. 1998, 338, 873.

10. Carmichael, W.W.; Azevedo, S.M.F.O.; AN, J.S.; Molica, R. J.R.; Jochimsen, E.M.; Lau, S.; Rinehart, K.L.; Shaw, G.R.; Eaglesham, G.K.; Environ. Health Persp. 2001, 109, 663.

11. Brasil, Portaria $n^{\circ} 518$ de 05 de março de 2004, D.O.U. de 26 de março de 2004, http://www.anvisa.br, acessed in January 2005.

12. Chu, F.S.; Huang, X.; Wei, R.D.; J. Assoc. Off Anal. Chem. 1990, 73, 451.

13. An, J.; Carmichael, W.W.; Toxicon 1994, 32, 1495.

14. Mcdermott, C.M.; Feola, R.; Plude, J.; Toxicon 1995, 33, 1433.

15. Nagata, S.; Tsutsumi, T.; Hasegawa, A.; Yoshida, F.; Ueno, Y.; J. AOAC Int. 1997, 80, 408.

16. Nagata, S.; Tsutsumi, T.; Yoshida, F.; Ueno, Y.; Nat. Toxins 1999, 7, 49.

17. Kim, Y.M.; Oh, S.W.; Jeong, S.Y.; Pyo, D.J.; Choi, E.Y.; Environ. Sci. Technol. 2003, 37, 1899.

18. de Sá, G.F.; Malta, O.L.; de Mello Donegá, C.; Simas, A.M.; Longo, R.L.; Santa-Cruz, P.A.; da Silva Jr., E.F.; Coord. Chem. Rev. 2000, 196, 165.

19. Mikola, H.; Takkalo, H.; Hemmilä, I.; Bioconjugate Chem. 1995, 6, 235.

20. Ronda, C.R.; J. Alloys Compd. 1995, 225, 534.

21. Gameiro, C.G.; Alves Jr, S.; Silva Jr, E.F.; Sá, G.F.; Santa-Cruz, P.A.; Mater. Forum 1998, 249, 315.

22. de Sá, G.F.; Alves Jr., S.; da Silva, B.J.P.; da Silva Jr., E.F.; Opt. Mater. 1998, 11, 23.

23. Takalo, H.; Mukkala, V.; Mikola, H.; Liitti, P.; Hemmilä, I.; Bioconjugate Chem. 1994, 5, 278.

24. Hemmilä, I.; Mukkala, V.; Takalo, H.; J. Alloys Compd. 1997, $249,158$.

25. Dakubu, S.; Hale, R.; Lu, A.; Quick, J.; Solas, D.; Wemberg, J.; Clin. Chem. 1988, 34, 1337. 
26. Mukkala, V.M.; Helenius, M.; Hemmila, I.; Kankare, J.; Takalo, H.; Helv. Chim. Acta 1993, 76, 1361.

27. Saha, A.K.; Kross, K.; Kloszewski, E.D.; Upsen, D.A.; Toner, J.L.; Snow, R.A.; Black, C.D.V.; Desais, V.C.; J. Am. Chem. Soc. 1993, 115, 11032.

28. Mehto, P.; Ankelo, M.; Hinkkanen, A.; Mikhailov, A.; Eriksson, J.E.; Spoof, L.; Meriluoto, J.; Toxicon 2001, 39, 831.

29. Soini, E.J.; Pelliniemi, L. J.; Hemmilä, I. A.; Mukkala, V.; Kankare, J. J.; Fröjdman, K.; J. Histochem. Cytochem. 1988, 36, 1449.

30. Bonin, E.; Tiru, M.; Hallander, H.; Bredberg, R.; J. Immunol. Methods 1999, 230, 131.

31. Xu, Y.; Hemmilä, I.; Lövgren, T.; Analyst 1991, 116, 155.

32. Sabbatini, N.; Guardigli, M.; Lehn, J.; Coord. Chem. Rev. 1993, 123, 201.

33. Prat, O.; Lopez, E.; Mathis, G.; Anal. Biochem. 1991, 195, 283.

34. Lopez, E.; Chypre, C.; Alha, B.; Mathis, G.; Clin. Chem. 1993, 39, 196.

35. Rodriguez-Ubis, J.; Béatrice, A.; Dominique, P.; Lehn, J.; Helv. Chim. Acta 1984, 67, 2264.

36. Lehn, J.M.; Regnouf de Vains, J.-B; Tetrahedron Lett. 1989 , 30, 2209.
37. Newkome, G.R.; Pappalardo, S.; Gupta, V.K.; Fronczek, F.R.; J. Org. Chem. 1983, 48, 4848.

38. Vila Nova, S. P.; Pereira, G. A. L.; Albuquerque, R.Q.; Mathis, G.; Bazin, H.; Autiero, H.; de Sa, G.F.; Alves Jr., S.; J. Lumin. 2004, 109, 173.

39. Vila Nova, S. P.; Pereira, G. A. L.; de Sá, G. F.; Alves Jr, S.; Bazin, H.; Autiero, H.; Mathis, G.; Quim. Nova 2004, 27, 709.

40. Moorhead, G.; MacKintosh, R. W.; Morrice, N.; Gallagher, T.; MacKintosh, C.; FEBS Lett. 1994, 356, 46.

41. Bradford, M.M.; Anal. Biochem. 1976, 72, 248.

42. Karnikowski, M.G.O.; Ph.D. Thesis, Universidade de Brasília, Brazil, 2001.

43. Roset, J.; Aguayo, S.; Muñoz, M.J.; Rev. Toxicol. 2001, $18,65$.

44. WHO In Guidelines for Drinking-Water Quality, $2^{\text {nd }}$ ed., Addendum to Volume 2, Health Criteria and Other Supporting Information; World Health Organization: Geneva, 1988.

45. Metcalf, J.S.; Gell, S.G.; Codd, G.A.; Water Res. 2000, 34, 2761.

46. Lei, L.-M.; Wu, Y.-S.; Gan, N.-Q.; Song, L.-R.; Clin. Chim. Acta 2004, 348, 177.

Received: January 4, 2005 Published on the web: January 18, 2006 